\title{
Monoclonal Antibodies Against Rat Brain Protein Kinase C and Their Application to Immunocytochemistry in Nervous Tissues
}

\author{
Tatsuro Kitano, ${ }^{1}$ Tadashi Hashimoto, ${ }^{1}$ Ushio Kikkawa, ${ }^{1}$ Katsuhiko Ase, ${ }^{1}$ Naoaki Saito, ${ }^{2}$ Chikako Tanaka, ${ }^{2}$ \\ Yuzo Ichimori, ${ }^{3}$ Kyozo Tsukamoto, ${ }^{3}$ and Yasutomi Nishizuka' \\ Departments of ${ }^{1}$ Biochemistry and ${ }^{2}$ Pharmacology, Kobe University School of Medicine, Kobe 650; and ${ }^{3}$ Central Research \\ Division, Takeda Chemical Industries, Osaka 532, Japan
}

\begin{abstract}
Three monoclonal antibodies were prepared against rat brain soluble protein kinase $\mathrm{C}$. Two of the antibodies, CKI-97 $\left(\mathrm{IgG}_{2 \mathrm{~b}}\right.$ subclass) and CKII-90 (IgG, subclass), showed weak binding to native protein kinase $\mathrm{C}$. The third antibody, CKI-33 $\left(\mathrm{IgG}_{2 \mathrm{~b}}\right.$ subclass), showed no binding. However, the mixture of CKI97, CKII-90, and CKI-33 exhibited much stronger binding activity to this protein kinase than any of the antlbodies alone. Although none of these antibodies showed protein kinase C-neutralizing activity, Western blot analysis indicated that these antibodies reacted specifically with protein kinase C, presumably its subspecies, that is present predominantly in nervous tissues. Immunocytochemical studies shows that these antibodies can be used for identification of this enzyme in nervous tissues. In rat Purkinje cells, the immunoreactive material was present throughout the cytoplasm, including dendrites and axons, but was poorly represented in the cell nucleus. In cerebellum, the localization of protein kinase $C$ appears to be very similar to that of CGMP-dependent protein kinase.
\end{abstract}

Protein kinase $\mathrm{C}$ has attracted a great deal of attention for studies on the activation of cellular function and proliferation, and our knowledge of the possible roles of this enzyme in cell-surface signal transduction is expanding rapidly (for reviews, see Nishizuka, 1984a, b, 1986; Kikkawa and Nishizuka, 1986). Under physiological conditions, protein kinase $\mathrm{C}$ is activated by association with phospholipids in the presence of diacylglycerol, which may arise transiently in membranes from receptor-mediated hydrolysis of inositol phospholipids (Takai et al., 1979; Kishimoto et al., 1980). It is also becoming clear that pleiotropic, if not all, actions of tumor-promoting phorbol esters are probably mediated through the action of this protein kinase, as first proposed by Castagna et al. (1982). Polyclonal antibodies against

\footnotetext{
Received Sept. 2, 1986; revised Dec. 5, 1986; accepted Dec. 15, 1986.

We are grateful to $S$. Nishiyama, $M$. Inatsugu, and $T$. Nishikori for their secretarial assistance, and also to $Y$. Toyoda for his skillful technical assistance. This work in the Departments of Biochemistry and Pharmacology, Kobe University School of Medicine, was supported in part by research grants from the Scientific Research Fund of Ministry of Education, Science and Culture, Japan (1985-86); Muscular Dystrophy Association (1985-86); Yamanouchi Foundation for Research on Metabolic Disorders (1985-86); Merck Sharp \& Dohme Research Laboratories (1986); Biotechnology Laboratories of Takeda Chemical Industries (198586); Ajinomoto Central Research Laboratories (1985-86); and Meiji Institute of Health Sciences (1985-86). The data were taken in part from the dissertation of T. Kitano to be submitted to Kobe University School of Medicine in partial fulfillment of the requirement for the degree of Doctor of Medical Science.

Correspondence should be addressed to Yasutomi Nishizuka at the above address.

Copyright (C) 1987 Society for Neuroscience $0270-6474 / 87 / 051520-06 \$ 02.00 / 0$
}

protein kinase $\mathrm{C}$ have been prepared using pig brain enzyme (Girard et al., 1985) or rat brain enzyme (Ballester and Rosen, $1985)$ as antigen. As one approach toward identifying the functional significance and structural features of this protein kinase, we have prepared monoclonal antibodies directed against rat brain protein kinase $\mathrm{C}$. The present paper describes characterization of 3 clones of the monoclonal antibodies designated CKI33, CKI-97, and CKII-90, which may recognize a subspecies of protein kinase $\mathrm{C}$ that is predominantly present in nervous tissues. An application of these antibodies to immunocytochemical studies of this enzyme in some rat nervous tissues will also be briefly presented.

\section{Materials and Methods}

Materials. Calf thymus $\mathrm{H}_{1}$ histone was prepared as described previously (Hashimoto et al., 1976). Formaldehyde-fixed, heat-killed Staphylococcus aureus (Cowan I) was obtained from Calbiochem and was used as an immunoadsorbant. The 8-azaguanine-resistant murine myeloma cell line P3-X63-Ag.U1 (P3U1) (Yelton et al., 1978) was obtained from Osaka University Medical School. Catalytic subunit of cAMP-dependent protein kinase was partially purified from rat heart by the method of Reimann and Beham (1983). cGMP-dependent protein kinase was prepared from bovine lung as described by Lincoln (1983). Glycogen phosphorylase $b$ kinase from rabbit skeletal muscle was donated by Dr. H. Yamamura, Fukui Medical School.

Purification of protein kinase $C$. Protein kinase $\mathrm{C}$ was purified from rat brain soluble fraction as described previously (Kikkawa et al., 1986). The enzyme preparation was nearly homogeneous by silver staining after SDS-PAGE.

Preparation of monoclonal antibodies. Male $\mathrm{BALB} / \mathrm{c}$ mice were injected intraperitoneally with $50 \mu \mathrm{g}$ of purified protein kinase $\mathrm{C}$ emulsified in an equal volume of complete Freund's adjuvant (DIFCO). Two weeks after the primary immunization, the same amount of antigen in incomplete Freund's adjuvant (DIFCO) was administrated subcutaneously. This treatment was repeated 10-12 times at 2 week intervals. Three subsequent immunizations were performed at 2-4 week intervals with purified enzyme in saline by intraperitoneal injections. During immunization, the mice were partially bled, and the sera were taken and used to detect antibodies against protein kinase $C$. Three days after final immunization, the splenocytes were isolated, mixed with 8-azaguanine-resistant parental cells (P3U1) at a ratio of 2:1, and fused by a modification of the procedure described by Köhler and Milstein (1975). The fused cells were suspended at $2 \times 10^{5}$ tumor cells $/ \mathrm{ml}$ in RPMI 1640 medium supplemented with $10^{-4} \mathrm{M}$ hypoxanthine, $4 \times 10^{-7} \mathrm{M}$ aminopterin, $1.6 \times 10^{-5} \mathrm{M}$ thymidine, and $10 \%$ fetal calf serum, and seeded in a volume of $1 \mathrm{ml}$ to each well of Linbro 24 well microplates (Flow Laboratories). The hybridomas were screened for anti-protein kinase $\mathrm{C}$ immunoglobulin secretion with an enzyme-linked immunosorbent assay (ELISA) technique. The hybridomas in wells that were found to be positive for the antibody production were cloned by the limiting dilution method in the presence of thymocytes from BALB/c mice as feeder cells. The cloned hybridomas were grown in the culture media, and antibodies against protein kinase $\mathrm{C}$ were detected by im- 


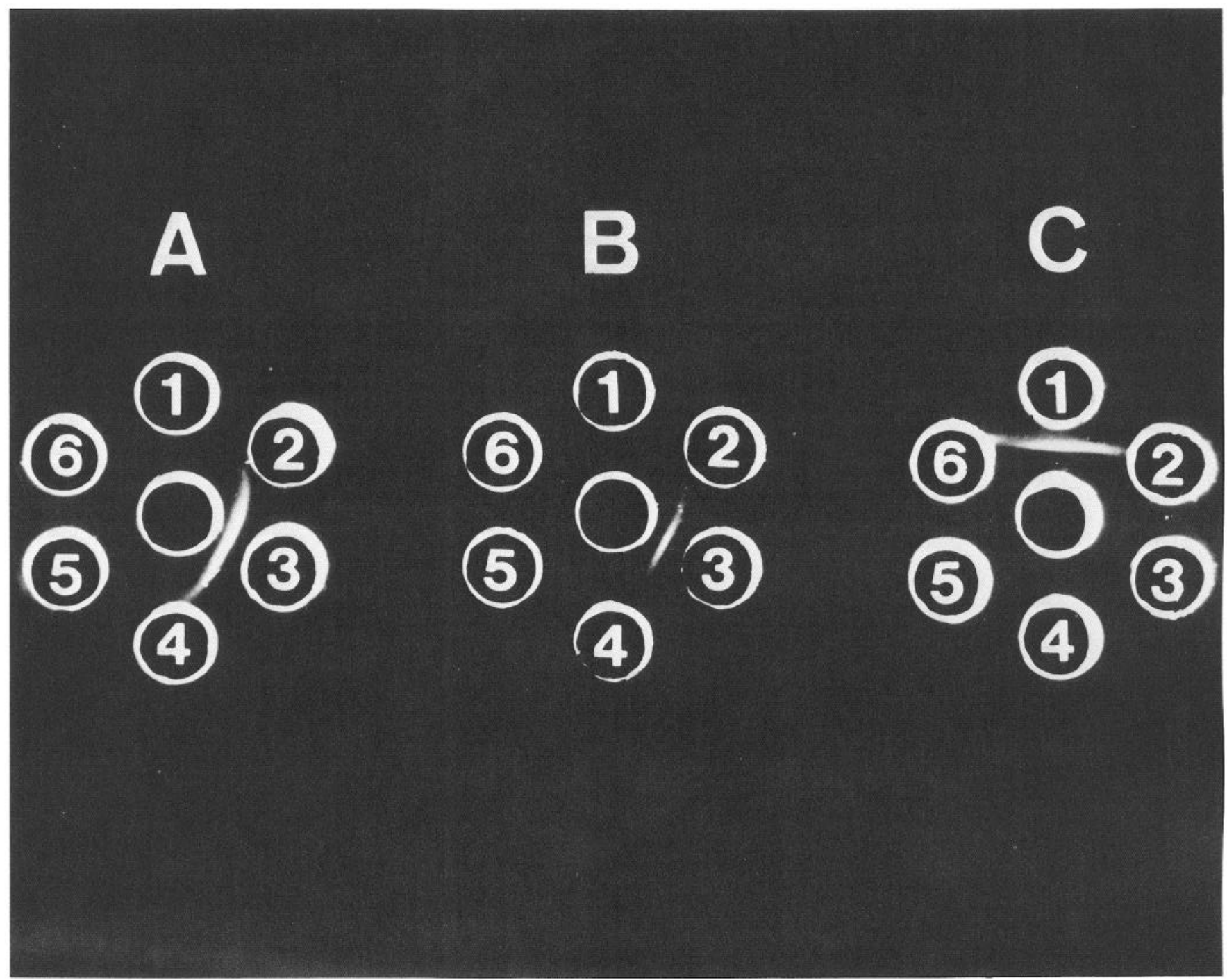

Figure 1. Immunodiffusion analysis of monoclonal antibodies against protein kinase $\mathrm{C}$. The classes and subclasses of monoclonal antibodies were determined by the Ouchterlony immunodiffusion method using class- or subclass-specific antisera to mouse immunoglobulin. $A$, CKI-33, $B$, CKI97 , and $C$, CKII-90. Center wells contained each purified monoclonal antibody. Wells $1-5$ contained rabbit antiserum to $\mathrm{mouse} \mathrm{IgG}_{1}, \mathrm{IgG}_{2 \mathrm{a}}, \mathrm{IgG}_{2 \mathrm{~b}}$, $\mathrm{IgG}_{3}$, and goat antiserum to mouse IgM, respectively. Well 6 contained PBS.

munoprecipitation and Western blot analysis using purified protein kinase $\mathrm{C}$ as antigen as described below.

Screening assay for antibodies. The ELISA technique was employed as a screening procedure to detect antibodies against protein kinase C in the sera of immunized mice and those in the culture supernatant of hybridomas. Purified protein kinase $\mathrm{C}$ was immobilized in wells of 96 well microtiter plates (Nunc InterMed) by incubating with $100 \mu \mathrm{l}$ of the enzyme solution ( $3 \mu \mathrm{g} / \mathrm{ml}$ in $10 \mathrm{~mm}$ sodium phosphate buffer at $\mathrm{pH} 8.0$ containing $10 \mathrm{~mm}$ sodium chloride) for $24 \mathrm{hr}$ at $4^{\circ} \mathrm{C}$. After the solution was removed by suction, the wells were incubated with $150 \mu \mathrm{l}$ of $2 \%$ (wt/vol) BSA in a PBS at least overnight at $4^{\circ} \mathrm{C}$ to block the remaining binding sites. The albumin solution was then discarded. Subsequently, $100 \mu \mathrm{l}$ of an antibody solution to be tested was added to each well, and the reaction was allowed to proceed for $3 \mathrm{hr}$ at room temperature or overnight at $4^{\circ} \mathrm{C}$. Antibody solutions either of serum, ascites fluid, or culture supernatant of hybrid cells were diluted to appropriate concentrations with PBS containing $1 \%(\mathrm{wt} / \mathrm{vol}) \mathrm{BSA}$. After removing the antibody solution, each well was washed 5 times with $0.15 \mathrm{M}$ sodium chloride, and then $100 \mu \mathrm{l}$ of 1:5000 dilution of peroxidase-conjugated goat antiserum to mouse immunoglobulins (IgG and IgM, Cappel Laboratories) in a PBS containing $1 \%$ (wt $/ \mathrm{vol}$ ) BSA was added. Incubation was for $3 \mathrm{hr}$ at room temperature. The wells were again washed extensively as before, and $100 \mu \mathrm{l}$ of $100 \mathrm{~mm}$ sodium citrate at pH 5.5 containing $0.2 \%(\mathrm{wt} / \mathrm{vol})$ orthophenylenediamine and $0.02 \% \mathrm{H}_{2} \mathrm{O}_{2}$ was added.
Wells containing antibodies against protein kinase $\mathrm{C}$ could be visually detected after 3-5 min at room temperature, and peroxidase reaction was stopped by adding $100 \mu \mathrm{l}$ of $4 \mathrm{~N} \mathrm{H}_{2} \mathrm{SO}_{4}$. The optical densities at $490 \mathrm{~nm}$ of each sample were read with automatic microwell plate colorimeter (ImmunoReader NJ-2000, Nippon InterMed).

Purification of monoclonal antibodies. Hybridomas $\left(2 \times 10^{6}\right.$ cells $)$ were injected intraperitoneally into $\mathrm{BALB} / \mathrm{c}$ mice pretreated with 0.5 $\mathrm{ml}$ of 2,6,10,14-tetra-methylpentadecane (Pristane, Aldrich) 1 week before. Most mice developed ascites within 2-3 weeks. Monoclonal antibodies were purified from ascites fluids by Protein A-Sepharose CL4B (Pharmacia) column chromatography as described by Ey et al. (1978). The classes and subclasses of the antibodies were confirmed by an immunodiffusion method (Ouchterlony, 1953) using class-specific goat antiserum to mouse IgM and subclass-specific rabbit antiserum to mouse IgG (Miles Laboratories). Nonimmune mouse IgG fraction was obtained from normal mouse sera by similar procedures.

Immunoprecipitation of protein kinase $C$ with monoclonal antibodies. Purified protein kinase $\mathrm{C}(0.1 \mu \mathrm{g})$ was incubated for $4 \mathrm{hr}$ at $10^{\circ} \mathrm{C}$ with monoclonal antibodies in $100 \mu \mathrm{l}$ of $20 \mathrm{~mm}$ Tris/HCl at $\mathrm{pH} 8.0$ containing $4 \mathrm{mg} / \mathrm{ml}$ BSA, 2 mм EGTA, $2 \mathrm{~mm}$ EDTA, $10 \mathrm{~mm}$ 2-mercaptoethanol, and $10 \%(\mathrm{wt} / \mathrm{vol})$ glycerol. After addition of $100 \mu \mathrm{l}$ of $10 \%(\mathrm{wt} / \mathrm{vol}) S$. aureus suspended in the same buffer solution, incubation was continued overnight at $10^{\circ} \mathrm{C}$. The $S$. aureus cells were removed by centrifugation for $2 \mathrm{~min}$ at $16,000 \times \mathrm{g}$, and an aliquot of the supernatant was assayed 


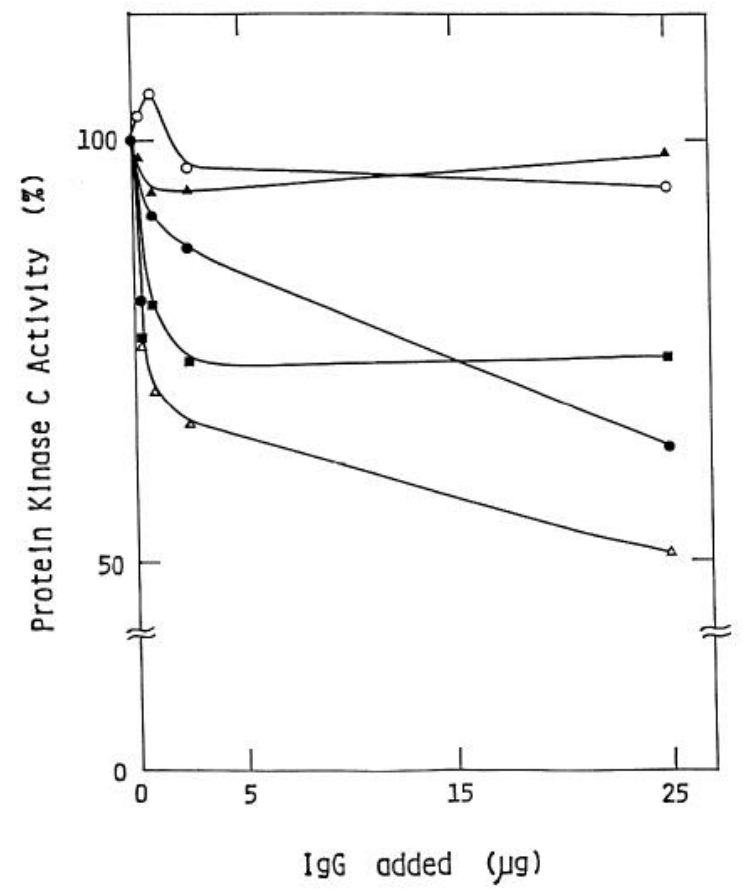

Figure 2. Immunoprecipitation of protein kinase $\mathrm{C}$ by monoclonal antibodies. Purified protein kinase $\mathrm{C}(0.1 \mu \mathrm{g})$ was incubated with the antibodies indicated: $\mathbf{\square}$, with CKI-97; $\bullet$, with CKII-90; $\boldsymbol{\Delta}$, with CKI$33 ; \Delta$, with a mixture of equal amounts of CKI-97, CKII-90, and CKI33 ; O, with normal mouse IgG fraction. Other details were described under Materials and Methods.

for the protein kinase $\mathrm{C}$ activity. Protein kinase $\mathrm{C}$ was assayed by measuring the incorporation of ${ }^{32} \mathrm{P}_{\text {into }}$ int $\mathrm{H}_{1}$ histone from $\gamma-{ }^{32} \mathrm{P}-\mathrm{ATP}$ as described (Kikkawa et al., 1986).

Western blot analysis. Purified protein kinase $\mathrm{C}$ and soluble fraction of rat brain were subjected to SDS-PAGE with a 1.0 -mm-thick $8.5 \%$ polyacrylamide slab gel by the method of Laemmli (1970). Proteins on the gel were electrophoretically transferred to nitrocellulose paper (BA $83, \mathrm{~S} \& \mathrm{~S})$ at $11.4 \mathrm{~V} / \mathrm{cm}$ electrode distance for $3 \mathrm{hr}$ at $4^{\circ} \mathrm{C}$ by the method of Towbin et al. (1979). After transfer, the nitrocellulose paper was rinsed with Tris- $\mathrm{NaCl}$ buffer $(10 \mathrm{~mm}$ Tris/ $/ \mathrm{HCl}, \mathrm{pH} 7.5$, containing 150 mM sodium chloride) containing $0.05 \%$ Tween 20 and was then incubated overnight at $4^{\circ} \mathrm{C}$ with PBS containing $5 \%$ (wt/vol) BSA and $20 \%$ ( $\mathrm{vol} / \mathrm{vol}$ ) horse serum to block remaining binding sites. Subsequent procedures were carried out at room temperature. The nitrocellulose paper was incubated for $30 \mathrm{~min}$ with monoclonal antibodies in Tris$\mathrm{NaCl}$ buffer containing $3 \%(\mathrm{wt} / \mathrm{vol}) \mathrm{BSA}$. After washing with Tris- $\mathrm{NaCl}$ buffer containing $0.05 \%$ Tween 20 , the nitrocellulose was incubated for 30 min with biotinylated anti-mouse IgG (Vectastain, Vector Laboratories), $1: 2200$ dilution in $50 \mathrm{~mm}$ Tris/ $\mathrm{HCl}$ at $\mathrm{pH}$ 7.5. The nitrocellulose was washed as before and incubated for $15 \mathrm{~min}$ with avidin-biotinylated HRP complex (Vectastain, Vector Laboratories). After washing with Tris- $\mathrm{NaCl}$ buffer containing $0.05 \%$ Tween 20 , the paper was incubated with $0.1 \%(\mathrm{wt} / \mathrm{vol})$ diaminobenzidine tetrahydrochloride and $0.02 \%$ $\mathrm{H}_{2} \mathrm{O}_{2}$. Development of the orange color was stopped by rinsing with distilled water. A duplicate of a blotting unit was used for protein staining with colloidal gold reagent (AuroDye, Janssen).

Immunocytochemical procedures. Immunocytochemical studies were carried out as described previously (Saito et al., 1986). The fixed cerebellum of Wistar rats was cut into sections $(20 \mu \mathrm{m})$, which were dipped directly in $0.1 \mathrm{~m}$ PBS containing $0.3 \%$ (wt/vol) Triton X-100. Subsequently, the sections were washed with the same buffer and incubated for $18 \mathrm{hr}$ at $4^{\circ} \mathrm{C}$ with monoclonal antibodies. The sections were then washed with PBS containing Triton X-100 and incubated for $2 \mathrm{hr}$ in fluorescein isothiocyanate-conjugated goat anti-mouse IgG (Miles Laboratories) diluted 1:250. After rinsing, the sections were mounted in buffered glycerol for fluorescent microscopic observation.

Protein determination. Protein was determined by the method of Bensadoun and Weinstein (1976) with BSA as a standard.

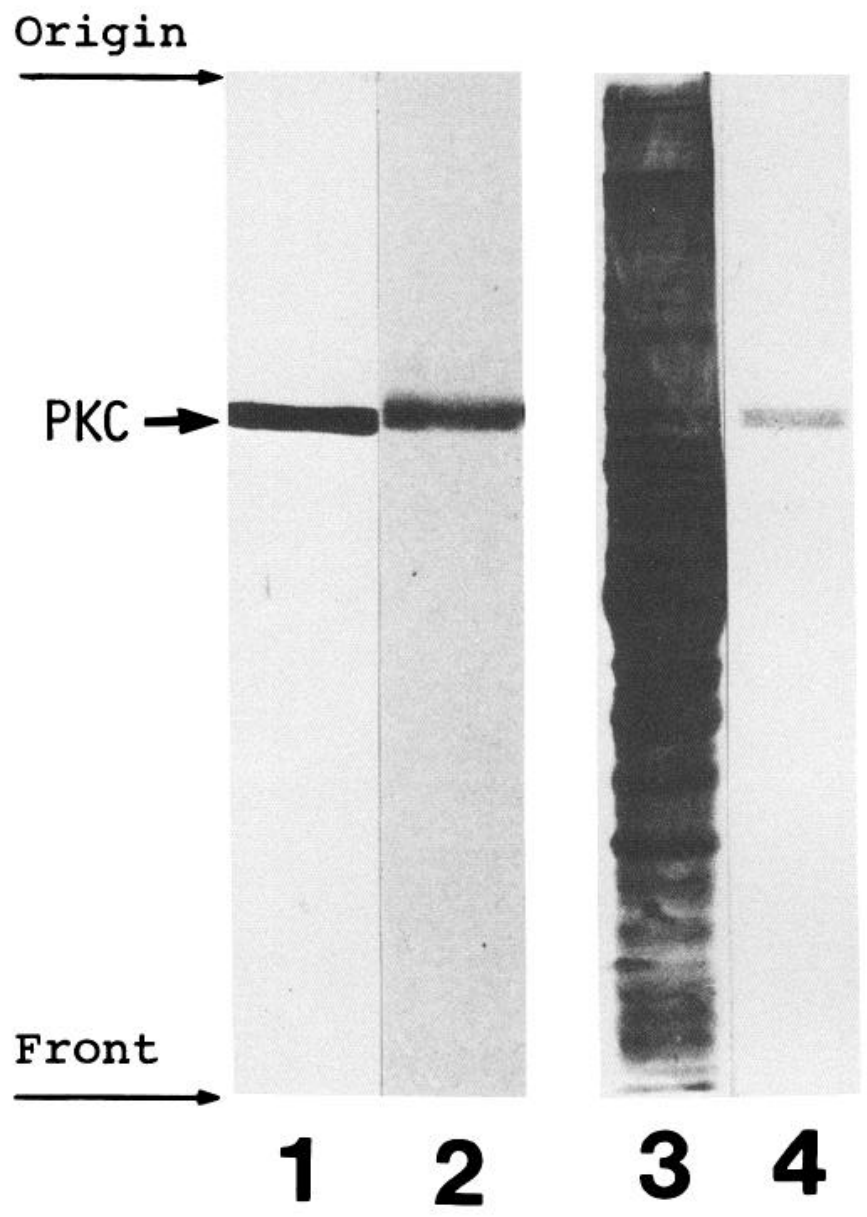

Figure 3. Western blot analysis of protein kinase $\mathrm{C}$ with monoclonal antibodies. Purified protein kinase $\mathrm{C}(2 \mu \mathrm{g})$ and soluble-fraction proteins $(75 \mu \mathrm{g})$ were subjected to SDS-PAGE, transferred to nitrocellulose, and stained with AuroDye or reacted with a mixture $(2 \mu \mathrm{g} / \mathrm{ml}$ of each) of monoclonal antibodies CKI-33, CKI-97, and CKII-90, as described under Materials and Methods. Lanes 1 and 3 are protein staining of purified protein kinase $\mathrm{C}$ and rat brain soluble fraction, respectively; lanes 2 and 4 show the results of Western blot analyses of lanes 1 and 3 , respectively. PKC, protein kinase C.

\section{Results and Discussion}

During immunization, the mice were partially bled, and the sera were assayed for antibodies against protein kinase $\mathrm{C}$ by the ELISA technique. After the 5th-10th immunization, the titer of the sera increased slightly. Finally, 3 clones, designated CKI33, CKI-97, and CKII-90 were established. These antibodies were classified as $\mathrm{IgG}$, because they bound to $S$. aureus cells directly and also reacted with biotinylated anti-mouse IgG antibodies by Western blot analysis. The chromatographic behaviors of CKI-33, CKI-97, and CKII-90 on Protein A-Sepharose column were consistent with their tentative assignment to the subclasses of $\operatorname{IgG}_{2 b}, \operatorname{IgG}_{2 b}$, and $\mathrm{IgG}_{1}$, respectively. Ouchterlony immunodiffusion analysis using the subclass-specific antisera to mouse IgG confirmed both CKI-33 and CKI-97 as IgG $_{2 b}$ antibodies, and CKII-90 as IgG $_{1}$ antibody as shown in Figure 1.

The binding activity of these monoclonal antibodies to protein kinase $\mathrm{C}$ was determined using $S$. aureus as shown in Figure 2. CKI-97 and CKII-90 showed binding activity to purified protein kinase $\mathrm{C}$, while $\mathrm{CKI}-33$ showed a very little binding activity to the native enzyme. The mixture of these 3 antibodies 

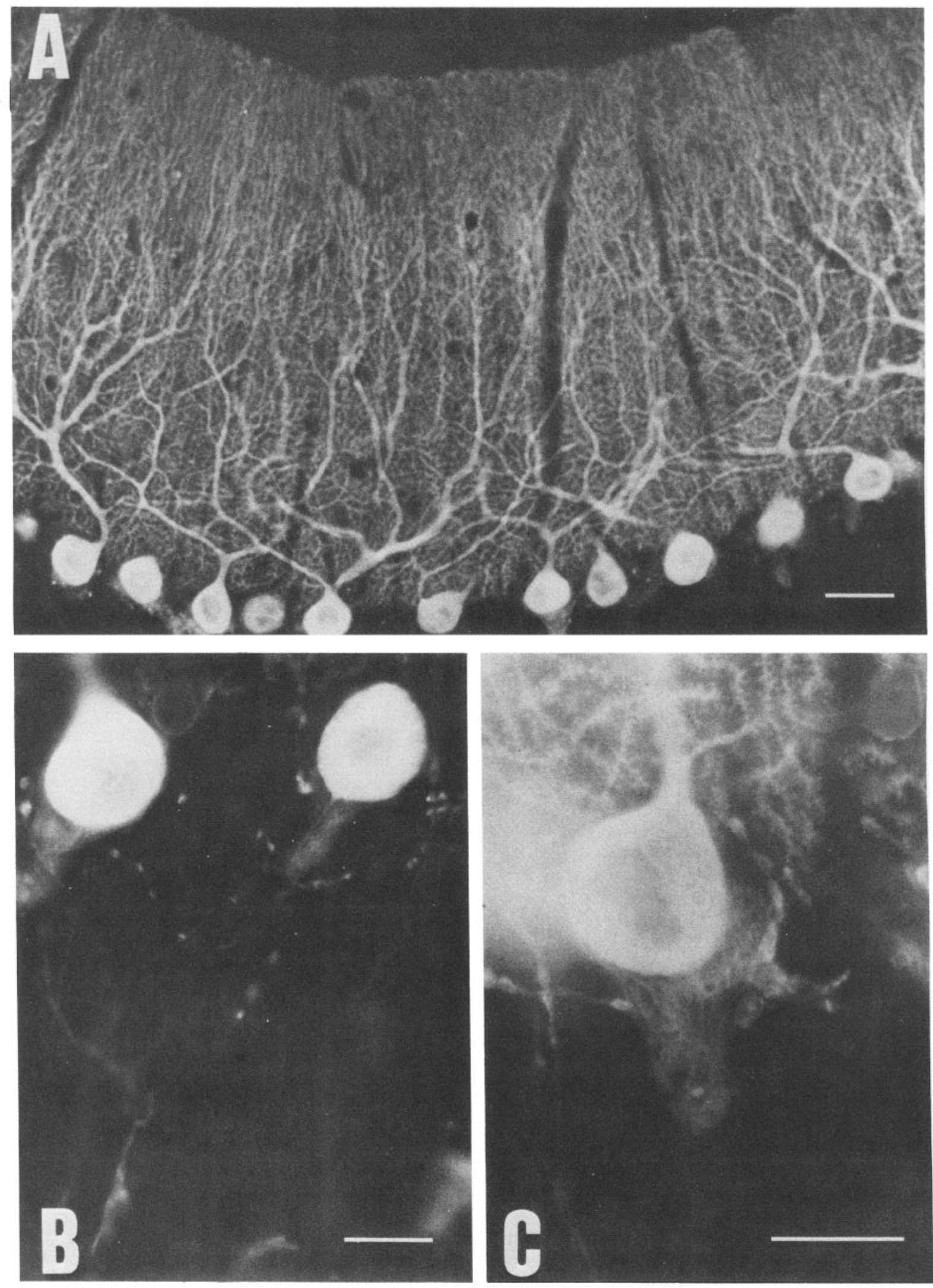

Figure 4. Immunocytochemical localization of protein kinase $\mathrm{C}$ in rat cerebellum. Sections of rat cerebellum were incubated with a mixture (1 $\mu \mathrm{g} / \mathrm{ml}$ of each) of monoclonal antibodies CKI-33, CKI-97, and CKII-90, and were stained by immunofluorescence as described under Materials and Methods. $A$, Low magnification (calibration bar, $100 \mu \mathrm{m}$ ); $B$ and $C$, high magnification (calibration bar, $50 \mu \mathrm{m}$ ). 
exhibited much stronger binding activity to this protein kinase. Thus, the affinity of these antibodies to protein kinase $\mathrm{C}$ seems to differ, and they probably recognize the different epitopes in this enzyme molecule. It was noted, however, that none of these monoclonal antibodies affected the catalytic activity of protein kinase $\mathrm{C}$ under the conditions where these antibodies bind to the enzyme.

Western blot analysis indicated that all of the 3 monoclonal antibodies CKI-33, CKI-97, and CKII-90 reacted with protein kinase C specifically. Figure 3 shows the results of Western blot analysis using a mixture of equal amounts of CKI-33, CKI-97, and CKII-90. Lane 1 indicates protein staining of the purified protein kinase $\mathrm{C}$ having an approximate molecular weight of $82 \mathrm{kDa}$, which matches the value previously estimated by SDSPAGE (Kikkawa et al., 1982). Lane 2 indicates that these antibodies reacted with purified protein kinase $C$. Among rat brain soluble proteins (lane 3 ), a protein band with a molecular weight corresponding to protein kinase $\mathrm{C}$ was specifically detected by these antibodies, as shown in lane 4 . Similar Western blot profiles were obtained with each of the 3 antibodies alone.

The antibodies defined above can be used for immunocytochemical studies of protein kinase $\mathrm{C}$ in many regions of rat nervous tissues. Figure 4 shows a typical result. In cerebellar cortex, a unique feature of Purkinje cells was stained, and the material was present throughout the cytoplasm, including dendrites and axons. The enzyme appeared to be absent or poorly represented in the nucleus. Identical immunocytochemical features were obtained when adjacent sections of this tissue were stained by each of the 3 antibodies alone. The immunoreaction was absorbed when these antibodies were pre-incubated with purified protein kinase $C$.

Biochemical fractionation of the brain tissues revealed that protein kinase $\mathrm{C}$ was distributed not only in soluble fraction but also in membranes (Kikkawa et al., 1982). No obvious differences were observed in the catalytic and kinetic properties of protein kinase $\mathrm{C}$ from different subcellular compartments. These antibodies also reacted with the membrane-associated protein kinase $\mathrm{C}$. In addition, protein kinase $\mathrm{C}$ purified from rat brain cytosol frequently revealed a double band upon SDSPAGE (Kikkawa et al., 1986). The antibodies CKI-33, CKI-97, and CKII-90 each recognized both proteins in this doublet. A recent analysis of complementary DNA clones has revealed that at least 3 , and probably more, subspecies of protein kinase $\mathrm{C}$ may exist in rat brain (Knopf et al., 1986; Ono et al., 1986a, b) and in bovine and human brain (Coussens et al., 1986). These subspecies of protein kinase $\mathrm{C}$ show a great similarity in their primary structures, having extensive sequence homologies. At present, we are unable to separate all of these subspecies from one another by conventional enzyme fractionation procedures. However, a preliminary analysis suggests that all subspecies of protein kinase $C$ are expressed in brain tissues and that the monoclonal antibodies described here recognize preferentially a subspecies that is present predominantly in nervous tissues. Protein kinase $\mathrm{C}$ isolated from some other tissues and cell types, such as neutrophils and fibroblasts, does not appear to react with these antibodies. It is possible that the incomplete precipitation of protein kinase $\mathrm{C}$ by these antibodies (see Fig. 2) results from the molecular heterogeneity of this enzyme.

It is also worth noting that protein kinase $C$ appears to show some amino acid sequence homology with the cAMP-dependent and cGMP-dependent protein kinases (Knopf et al., 1986; Ono et al., 1986a, b; Parker et al., 1986). However, Western blot analysis indicated that the antibodies described above did not react with the catalytic subunit of cAMP-dependent protein kinase from rat heart, cGMP-dependent protein kinase from bovine lung, or any subunit of glycogen phosphorylase $b$ kinase from rabbit skeletal muscle. So far, protein kinase $C$ appeared to be the sole protein in crude tissue extracts detectable by Western blot analysis. Nevertheless, in rat cerebellum, the localization of protein kinase $\mathrm{C}$ detected by the monoclonal antibodies is apparently very similar to that of cGMP-dependent protein kinase reported by De Camilli et al. (1984).

Kuo and his collaborators (Girard et al., 1985; Wood et al., 1986) have shown immunocytochemical localization of protein kinase $\mathrm{C}$ in rat brain using their polyclonal antibodies. They observed little dendritic staining but did note prominent nuclear staining highly restricted to the periphery of the nucleus of Purkinje cells. Their antibodies were revealed to recognize 80 and $67 \mathrm{kDa}$ protein bands by Western blot analysis (Girard et al., 1985). This $80 \mathrm{kDa}$ protein seems to be protein kinase $C$ itself. However, in the present studies a $67 \mathrm{kDa}$ protein was not detected. The 2 sets of antibodies obtained in their and our laboratories may be recognizing different subspecies of protein kinase $\mathrm{C}$, or the different results of immunocytochemical studies may result from methodological differences in fixation and staining. However, the precise reason of the different results of immunochemical studies is not clear at present.

Autoradiographic analysis with ${ }^{3} \mathrm{H}$-phorbol-12,13-dibutyrate by Worley et al. (1986a-c) has demonstrated the localization of phorbol ester-binding protein in rat brain, which may represent protein kinase $C$. The present studies have shown that the distribution pattern of protein kinase $\mathrm{C}$ stained by the immunocytochemical procedure is very similar to that of the phorbol ester-binding protein. The results of further studies on the detailed nature of subspecies, as well as the precise localization of protein kinase $C$ within the brain and various neuronal cells, will be described in subsequent papers of this series.

\section{References}

Ballester, R., and O. M. Rosen (1985) Fate of immunoprecipitable protein kinase $\mathrm{C}$ in $\mathrm{GH}_{3}$ cells treated with phorbol 12-myristate 13acetate. J. Biol. Chem. 260: 15194-15199.

Bensadoun, A., and D. Weinstein (1976) Assay of proteins in the presence of interfering materials. Anal. Biochem. 70: 241-250.

Castagna, M., Y. Takai, K. Kaibuchi, K. Sano, U. Kikkawa, and Y. Nishizuka (1982) Direct activation of calcium-activated, phospholipid-dependent protein kinase by tumor-promoting phorbol esters. J. Biol. Chem. 257: 7847-7851.

Coussens, L., P. J. Parker, L. Rhee, T. L. Yang-Feng, E. Chen, M. D. Waterfield, U. Francke, and A. Ullich (1986) Multiple, distinct forms of bovine and human protein kinase $C$ suggest diversity in cellular signaling pathways. Science 233: 859-866.

De Camilli, P., P. E. Miller, P. Levitt, U. Walter, and P. Greengard (1984) Anatomy of cerebellar Purkinje cells in the rat determined by a specific immunohistochemical marker. Neuroscience 11:761817.

Ey, P. L., S. J. Prowse, and C. R. Jenkin (1978) Isolation of pure IgG $_{1}$, $\mathrm{IgG}_{2 \mathrm{a}}$, and $\mathrm{IgG}_{2 \mathrm{~b}}$ immunoglobulins from mouse serum using protein A-Sepharose. Immunochemistry 15: 429-436.

Girard, P. R., G. J. Mazzei, J. G. Wood, and J. F. Kuo (1985) Polyclonal antibodies to phospholipid $/ \mathrm{Ca}^{2+}$-dependent protein kinase and immunocytochemical localization of the enzyme in rat brain. Proc. Natl. Acad. Sci. USA 82: 3030-3034.

Hashimoto, E., M. Takeda, Y. Nishizuka, K. Hamana, and K. Iwai (1976) Studies on the sites in histones phosphorylated by adenosine $3^{\prime}: 5^{\prime}$-monophosphate-dependent protein kinases. J. Biol. Chem. 251 : 6287-6293. 
Kikkawa, U., and Y. Nishizuka (1986) The role of protein kinase C in transmembrane signalling. Annu. Rev. Cell Biol. 2: 149-178.

Kikkawa, U., Y. Takai, R. Minakuchi, S. Inohara, and Y. Nishizuka (1982) Calcium-activated, phospholipid-dependent protein kinase from rat brain. Subcellular distribution, purification, and properties. J. Biol. Chem. 257: 13341-13348.

Kikkawa, U., M. Go, J. Koumoto, and Y. Nishizuka (1986) Rapid purification of protein kinase $\mathrm{C}$ by high performance liquid chromatography. Biochem. Biophys. Res. Commun. 135: 636-643.

Kishimoto, A., Y. Takai, T. Mori, U. Kikkawa, and Y. Nishizuka (1980) Activation of calcium and phospholipid-dependent protein kinase by diacylglycerol, its possible relation to phosphatidylinositol turnover. J. Biol. Chem. 255: 2273-2276.

Knopf, J. L., M.-H. Lee, L. A. Sultzman, R. W. Kriz, C. R. Loomis, R. M. Hewick, and R. M. Bell (1986) Cloning and expression of multiple protein kinase C cDNAs. Cell 46: 491-502.

Köhler, G., and C. Milstein (1975) Continuous cultures of fused cells secreting antibody of predefined specificity. Nature 256: 495-497.

Laemmli, U. K. (1970) Cleavage of structural proteins during the assembly of the head of bacteriophage $T_{4}$. Nature 227:680-685.

Lincoln, T. M. (1983) cGMP-dependent protcin kinase. Methods Enzymol. 99: 62-71.

Nishizuka, Y. (1984a) The role of protein kinase C in cell surface signal transduction and tumour promotion. Nature 308: 693-698.

Nishizuka, Y. (1984b) Turnover of inositol phospholipids and signal transduction. Science 225: 1365-1370.

Nishizuka, Y. (1986) Studies and perspectives of protein kinase C. Science 233: 305-312.

Ono, Y., T. Kurokawa, K. Kawahara, O. Nishimura, R. Marumoto, K. Igarashi, Y. Sugino, U. Kikkawa, K. Ogita, and Y. Nishizuka (1986a) Cloning of rat brain protein kinase C complementary DNA. FEBS Lett. 203: 111-115.

Ono, Y., T. Kurokawa, T. Fujii, K. Kawahara, K. Igarashi, U. Kikkawa, K. Ogita, and Y. Nishizuka (1986b) Two types of complementary DNAs of rat brain protein kinase C, hetcrogencity determincd by alternative splicing. FEBS Lett. 206: 347-352.
Ouchterlony, O. (1953) Antigen antibody reaction in gels. Acta Pathol. Microbiol. Scand. 32: 231-240.

Parker, P. J., L. Coussens, N. Totty, L. Rhee, S. Young, E. Chen, S. Stabel, M. D. Waterfield, and A. Ullich (1986) The complete primary structure of protein kinase $\mathrm{C}$ - the major phorbol ester receptor. Science 233: 853-859.

Reimann, E. M., and R. A. Beham (1983) Catalytic subunit of cAMPdependent protein kinase. Methods Enzymol. 99: 51-55.

Saito, N., K. Kumoi, and C. Tanaka (1986) Aspartate-like immunoreactivity in mitral cells of rat olfactory bulb. Neurosci. Lett. 65:8993.

Takai, Y., A. Kishimoto, U. Kikkawa, T. Mori, and Y. Nishizuka (1979) Unsaturated diacylglycerol as a possible messenger for the activation of calcium-activated, phospholipid-dependent protein kinase system. Biochem. Biophys. Res. Commun. 91: 1218-1224.

Towbin, H., T. Staehelin, and J. Gordon (1979) Electrophoretic transfer of proteins from polyacrylamide gels to nitrocellulose sheets; procedure and some applications. Proc. Natl. Acad. Sci. USA 76: 43504354.

Wood, J. G., P. R. Girard, G. J. Mazzei, and J. F. Kuo (1986) Immunocytochemical localization of protein kinase $C$ in identified ncuronal compartments of rat brain. J. Neurosci. 6: 2571-2577.

Worley, P. F., J. M. Baraban, and S. H. Snyder (1986a) Heterogeneous localization of protein kinase $\mathrm{C}$ in rat brain: Autoradiographic analysis of phorbol ester receptor binding. J. Neurosci. 6: 199-207.

Worley, P. F., J. M. Baraban, E. B. De Souza, and S. H. Snyder (1986b) Mapping second messenger systems in the brain: Differential localizations of adenylate cyclase and protein kinase C. Proc. Natl. Acad. Sci. USA 83: 4053-4057.

Worley, P. F., J. M. Baraban, C. Van Dop, E. J. Neer, and S. H. Snyder (1986c) $\mathrm{G}_{0}$, a guanine nucleotide-binding protein: Immunohistochemical localization in rat brain resembles distribution of second messenger systems. Proc. Natl. Acad. Sci. USA 83: 4561-4565.

Yelton, D. E., B. A. Diamond, S. P. Kwan, and M. D. Scharff (1978) Fusion of mouse myeloma and spleen cells. Curr. Top. Microbiol. Immunol. 81: 1-7. 